Tropical Journal of Pharmaceutical Research April 2017; 16 (4): 849-854

ISSN: $1596-5996$ (print); 1596-9827 (electronic)

(C) Pharmacotherapy Group, Faculty of Pharmacy, University of Benin, Benin City, 300001 Nigeria.

All rights reserved.

Available online at http://www.tjpr.org

Original Research Article

http://dx.doi.org/10.4314/tjpr.v16i4.14

\title{
Determination of activities of human carbonic anhydrase II inhibitors from curcumin analogs
}

\author{
Reza Aditama ${ }^{1}$, Yum Eryanti ${ }^{2}$, Didin Mujahidin ${ }^{3}$, Yana Maolana Syah ${ }^{3}$, Rukman \\ Hertadi $^{1 *}$ \\ ${ }^{1}$ Biochemistry Research Group, Faculty of Mathematics and Natural Sciences, Bandung Institute of Technology, Jalan \\ Ganesha 10, Bandung 40132, 'Laboratory of Organic Synthesis, Department of Chemistry, Faculty of Mathematics and Natural \\ Sciences, University of Riau, Pekanbaru, 26293, ${ }^{3}$ Organic Research Group, Faculty of Mathematics and Natural Sciences, \\ Bandung Institute of Technology, Jalan Ganesha 10, Bandung 40132, Indonesia
}

${ }^{\star}$ For correspondence: Email: rukman@chem.itb.ac.id; Tel: +6281321174370

Revised accepted: 9 March 2017

\begin{abstract}
Purpose: To evaluate the activities of new curcumin analogs as carbonic anhydrase II (CA-II) inhibitor. Methods: Carbonic anhydrase II (CA-II) inhibition was determined by each ligand capability to inhibit the esterase activity of CA-II using 4-NPA as a substrate in 96-well plates. Dimethyl sulfoxide was used to dissolve each curcumin analog compound, and then diluted with biological buffer. They were then mixed with CA-II solution and to start the reaction, 4-NPA was added. Hydrolysis of the substrate was evaluated at $405 \mathrm{~nm}$ after incubation for $2 \mathrm{~h}$ at $25{ }^{\circ} \mathrm{C}$. The $I C_{50}$ value of compounds with inhibitory activity higher than $40 \%$ was then evaluated. Molecular docking was also used to predict enzymeinhibitor interaction.

Results: Eight new curcumin analogs were potent to inhibit $C A-I /$ activity with $I C_{50}$ values ranging from $7.92 \pm 0.54$ to $72.31 \pm 2.21 \mu \mathrm{mol}$; the lowest value was exhibited by $(3 E, 5 E)-3,5-$ bis $[(2-$ hydroxyphenyl)methylidene]piperidin-4-one (a1). Molecular docking analysis revealed that this molecule formed hydrogen bonds with Thr199, Thr200 and GIn92 at the active site of CA-II.

Conclusion: These curcumin analogs have inhibitory potential against CA-II; (3E, 5E)-3,5-bis[(2hydroxyphenyl)methylideneJpiperidin-4-one (a1) has the highest inhibitory activity and may be useful in the development of CA-II inhibitors for glaucoma treatment.
\end{abstract}

Keywords: Carbonic anhydrase II inhibitor, Curcumin analogs, Molecular docking

Tropical Journal of Pharmaceutical Research is indexed by Science Citation Index (SciSearch), Scopus, International Pharmaceutical Abstract, Chemical Abstracts, Embase, Index Copernicus, EBSCO, African Index Medicus, JournalSeek, Journal Citation Reports/Science Edition, Directory of Open Access Journals (DOAJ), African Journal Online, Bioline International, Open-J-Gate and Pharmacy Abstracts

\section{INTRODUCTION}

The general function of carbonic anhydrase (CA) is to catalyze the reversible conversion of carbon dioxide and water to a bicarbonate ion and a proton [1-3]. Misregulation of this enzyme has been linked to many diseases, such as glaucoma, cancer, and epilepsy [4,5]. The isozyme CA-II is known to be one of the most efficient in $\mathrm{CO}_{2}$ hydration [2]. Sulfonamide compounds, which are known as strong inhibitors of CA-II, have been used as commercial drugs to treat glaucoma [6]. However, these drugs produce many undesired side effects. Therefore, intensive search for novel drugs is ongoing, through synthesis of new derivatives of known drugs or from new molecular bases. Systematic search for new molecular bases is usually undertaken by exploring compounds from natural products $[7,8]$.

Curcumin and related compounds show promising result as a molecular base on which to design novel inhibitors of CA-II [9]. Due to the 
amounts and the variety of curcuminoids from natural sources are limited, methods of synthesizing curcumin and its analogs have been explored [10].

In the present study, 44 novel curcumin analogs, previously synthesized using microwave irradiation [10], were evaluated for their potential as inhibitors of human CA-II. The basic structure of all 44 curcumin analogs is depicted in Figure 1.

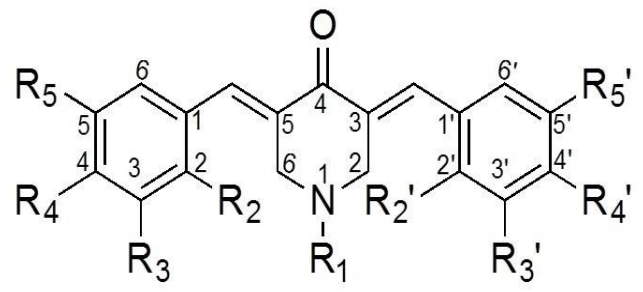

Figure 1: Basic structure of curcumin analogs

Table 1: List of ligand molecules

\begin{tabular}{|c|c|c|}
\hline Compound & Structure & Inhibition (\%) \\
\hline a1 & $\mathrm{R}_{1}=\mathrm{H}, \mathrm{R}_{2}=\mathrm{R}_{2}^{\prime}=\mathrm{OH}$ & 81.44 \\
\hline a2 & $\mathrm{R}_{1}=\mathrm{H}, \mathrm{R}_{2}=\mathrm{R}_{2}^{\prime}=\mathrm{Cl}$ & 8.89 \\
\hline a3 & $\mathrm{R}_{1}=\mathrm{H}, \mathrm{R}_{2}=\mathrm{R}_{2}=\mathrm{OCH}_{3}$ & 49.37 \\
\hline a4 & $\mathrm{R}_{1}=\mathrm{H}, \mathrm{R}_{3}=\mathrm{R}_{3}=\mathrm{OH}$ & 11.43 \\
\hline a5 & $\mathrm{R}_{1}=\mathrm{H}, \mathrm{R}_{3}=\mathrm{R}_{3}=\mathrm{Br}$ & 14.90 \\
\hline a7 & $\mathrm{R}_{1}=\mathrm{H}, \mathrm{R}_{3}=\mathrm{R}_{3}=\mathrm{OCH}_{3}$ & n.a. \\
\hline a8 & $\mathrm{R}_{1}=\mathrm{H}, \mathrm{R}_{4}=\mathrm{R}_{4}=\mathrm{OH}$ & n.a. \\
\hline a9 & $\mathrm{R}_{1}=\mathrm{H}, \mathrm{R}_{4}=\mathrm{R}_{4}=\mathrm{Cl}$ & n.a. \\
\hline a10 & $\mathrm{R}_{1}=\mathrm{H}, \mathrm{R}_{4}=\mathrm{R}_{4}=\mathrm{OCH}_{3}$ & 0.00 \\
\hline a11 & $\mathrm{R}_{1}=\mathrm{H}, \mathrm{R}_{4}=\mathrm{R}_{4}{ }^{\prime}=\mathrm{N}\left(\mathrm{CH}_{3}\right)_{2}$ & 7.56 \\
\hline a12 & $\mathrm{R}_{1}=\mathrm{H}, \mathrm{R}_{2}=\mathrm{R}_{3}=\mathrm{R}_{2}=\mathrm{R}_{3}=\mathrm{OCH}_{3}$ & 0.68 \\
\hline a13 & $\mathrm{R}_{1}=\mathrm{H}, \mathrm{R}_{2}=\mathrm{R}_{5}=\mathrm{R}_{2}^{\prime}=\mathrm{R}_{5}{ }^{\prime}=\mathrm{OCH}_{3}$ & n.a. \\
\hline a14 & $\mathrm{R}_{1}=\mathrm{H}, \mathrm{R}_{3}=\mathrm{R}_{4}=\mathrm{R}_{3}{ }^{\prime}=\mathrm{R}_{4}{ }^{\prime}=\mathrm{OCH}_{3}$, & 0.00 \\
\hline a15 & $\mathrm{R}_{1}=\mathrm{H}, \mathrm{R}_{2}=\mathrm{R}_{4}=\mathrm{R}_{5}=\mathrm{R}_{2}{ }^{\prime}=\mathrm{R}_{4}^{\prime}=\mathrm{R}_{5}^{\prime}=\mathrm{OCH}_{3}$ & 0.00 \\
\hline a16 & $\mathrm{R}_{1}=\mathrm{H}, \mathrm{R}_{3}=\mathrm{R}_{4}=\mathrm{R}_{5}=\mathrm{R}_{3}{ }^{\prime}=\mathrm{R}_{4}^{\prime}=\mathrm{R}_{5}{ }^{\prime}=\mathrm{OCH}_{3}$ & 0.00 \\
\hline b1 & $\mathrm{R}_{1}=\mathrm{CH}_{3}, \mathrm{R}_{2}=\mathrm{R}_{2}^{\prime}=\mathrm{OH}$ & 0.00 \\
\hline b2 & $\mathrm{R}_{1}=\mathrm{CH}_{3}, \mathrm{R}_{2}=\mathrm{R}_{2}=\mathrm{Cl}$ & 8.02 \\
\hline b3 & $\mathrm{R}_{1}=\mathrm{CH}_{3}, \mathrm{R}_{2}=\mathrm{R}_{2}^{\prime}=\mathrm{OCH}_{3}$ & 0.00 \\
\hline b4 & $\mathrm{R}_{1}=\mathrm{CH}_{3}, \mathrm{R}_{3}=\mathrm{R}_{3}=\mathrm{OH}$ & 17.71 \\
\hline b6 & $\mathrm{R}_{1}=\mathrm{CH}_{3}, \mathrm{R}_{5}=\mathrm{R}_{5}^{\prime}=\mathrm{Br}$ & 18.42 \\
\hline b7 & $\mathrm{R}_{1}=\mathrm{CH}_{3}, \mathrm{R}_{3}=\mathrm{R}_{3}^{\prime}=\mathrm{OCH}_{3}$ & n.a. \\
\hline b8 & $\mathrm{R}_{1}=\mathrm{CH}_{3}, \mathrm{R}_{4}=\mathrm{R}_{4}^{\prime}=\mathrm{OH}$ & 3.79 \\
\hline b9 & $\mathrm{R}_{1}=\mathrm{CH}_{3}, \mathrm{R}_{4}=\mathrm{R}_{4}^{\prime}=\mathrm{Cl}$ & 40.60 \\
\hline b10 & $\mathrm{R}_{1}=\mathrm{CH}_{3}, \mathrm{R}_{4}=\mathrm{R}_{4}=\mathrm{OCH}_{3}$ & 0.00 \\
\hline b11 & $\mathrm{R}_{1}=\mathrm{CH}_{3}, \mathrm{R}_{4}=\mathrm{R}_{4}^{\prime}=\mathrm{N}\left(\mathrm{CH}_{3}\right)_{2}$ & 0.00 \\
\hline b12 & $\mathrm{R}_{1}=\mathrm{CH}_{3}, \mathrm{R}_{2}=\mathrm{R}_{3}=\mathrm{R}_{2}^{\prime}=\mathrm{R}_{3}^{\prime}=\mathrm{OCH}_{3}$ & 15.62 \\
\hline b13 & $\mathrm{R}_{1}=\mathrm{CH}_{3}, \mathrm{R}_{2}=\mathrm{R}_{5}=\mathrm{R}_{2}=\mathrm{R}_{5}=\mathrm{OCH}_{3}$ & 12.41 \\
\hline b14 & $\mathrm{R}_{1}=\mathrm{CH}_{3}, \mathrm{R}_{3}=\mathrm{R}_{4}=\mathrm{R}_{3}{ }^{\prime}=\mathrm{R}_{4}{ }^{\prime}=\mathrm{OCH}_{3}$ & 0.00 \\
\hline b15 & $\mathrm{R}_{1}=\mathrm{CH}_{3}, \mathrm{R}_{2}=\mathrm{R}_{4}=\mathrm{R}_{5}=\mathrm{R}_{2}^{\prime}=\mathrm{R}_{4}^{\prime}=\mathrm{R}_{5}^{\prime}=\mathrm{OCH}_{3}$ & 14.85 \\
\hline b16 & $\mathrm{R}_{1}=\mathrm{CH}_{3}, \mathrm{R}_{3}=\mathrm{R}_{4}=\mathrm{R}_{5}=\mathrm{R}_{3}{ }^{\prime}=\mathrm{R}_{4}{ }^{\prime}=\mathrm{R}_{5}{ }^{\prime}=\mathrm{OCH}_{3}$ & 12.30 \\
\hline c1 & $\mathrm{R}_{1}=\mathrm{C}_{7} \mathrm{H}_{7}, \mathrm{R}_{2}=\mathrm{R}_{2}{ }^{\prime}=\mathrm{OH}$ & 27.09 \\
\hline c2 & $\mathrm{R}_{1}=\mathrm{C}_{7} \mathrm{H}_{7}, \mathrm{R}_{2}=\mathrm{R}_{2}=\mathrm{Cl}$ & 22.20 \\
\hline c3 & $\mathrm{R}_{1}=\mathrm{C}_{7} \mathrm{H}_{7}, \mathrm{R}_{2}=\mathrm{R}_{2}=\mathrm{OCH}_{3}$ & 0.00 \\
\hline c4 & $\mathrm{R}_{1}=\mathrm{C}_{7} \mathrm{H}_{7}, \mathrm{R}_{3}=\mathrm{R}_{3}=\mathrm{OH}$ & 19.09 \\
\hline c6 & $\mathrm{R}_{1}=\mathrm{C}_{7} \mathrm{H}_{7}, \mathrm{R}_{5}=\mathrm{R}_{5}=\mathrm{Br}$ & 40.65 \\
\hline c7 & $\mathrm{R}_{1}=\mathrm{C}_{7} \mathrm{H}_{7}, \mathrm{R}_{3}=\mathrm{R}_{3}=\mathrm{OCH}_{3}$ & 48.66 \\
\hline c8 & $\mathrm{R}_{1}=\mathrm{C}_{7} \mathrm{H}_{7}, \mathrm{R}_{4}=\mathrm{R}_{4}{ }^{\prime}=\mathrm{OH}$ & 19.09 \\
\hline c9 & $\mathrm{R}_{1}=\mathrm{C}_{7} \mathrm{H}_{7}, \mathrm{R}_{4}=\mathrm{R}_{4}{ }^{\prime}=\mathrm{Cl}$ & 41.32 \\
\hline c10 & $\mathrm{R}_{1}=\mathrm{C}_{7} \mathrm{H}_{7}, \mathrm{R}_{4}=\mathrm{R}_{4}{ }^{\prime}=\mathrm{OCH}_{3}$ & 58.50 \\
\hline $\mathrm{c} 11$ & $\mathrm{R}_{1}=\mathrm{C}_{7} \mathrm{H}_{7}, \mathrm{R}_{4}=\mathrm{R}_{4}^{\prime}=\mathrm{N}\left(\mathrm{CH}_{3}\right)_{2}$ & 0.00 \\
\hline c12 & $\mathrm{R}_{1}=\mathrm{C}_{7} \mathrm{H}_{7}, \mathrm{R}_{2}=\mathrm{R}_{3}=\mathrm{R}_{2}{ }^{\prime}=\mathrm{R}_{3}{ }^{\prime}=\mathrm{OCH}_{3}$ & 53.45 \\
\hline $\mathrm{c} 13$ & $\mathrm{R}_{1}=\mathrm{C}_{7} \mathrm{H}_{7}, \mathrm{R}_{2}=\mathrm{R}_{5}=\mathrm{R}_{2}{ }^{\prime}=\mathrm{R}_{5}^{\prime}=\mathrm{OCH}_{3}$ & 43.25 \\
\hline c14 & $\mathrm{R}_{1}=\mathrm{C}_{7} \mathrm{H}_{7}, \mathrm{R}_{3}=\mathrm{R}_{4}=\mathrm{R}_{3}{ }^{\prime}=\mathrm{R}_{4}{ }^{\prime}=\mathrm{OCH}_{3}$ & 0.00 \\
\hline c16 & $\mathrm{R}_{1}=\mathrm{C}_{7} \mathrm{H}_{7}, \mathrm{R}_{3}=\mathrm{R}_{4}=\mathrm{R}_{5}=\mathrm{R}_{3}{ }^{\prime}=\mathrm{R}_{4}^{\prime}=\mathrm{R}_{5}^{\prime}=\mathrm{OCH}_{3}$ & n.a. \\
\hline
\end{tabular}

\section{EXPERIMENTAL}

\section{Materials}

Table 1.
All inhibitors were synthesized using microwave irradiation methods, as described in a previous study [10]. The side groups of each inhibitor are shown 


\section{CA-II inhibition assay}

Measurement of the reduction in esterase activity on the substrate p-nitrophenyl acetate (4-NPA) was used to perform CA II inhibition assay [11]. The assay was divided into two sections-a pretest and an evaluation test. The former was performed to screen inhibitor molecules that have at least a $40 \%$ inhibitory effect, while the latter was undertaken by measuring $\mathrm{IC}_{50}$ values for the molecules selected in the previous test.

For comparison, the inhibitory activity of a commercial inhibitor, acetazolamide, which is known as a strong inhibitor of CA-II activity was used as standard $[7,12,13]$. All inhibitor samples were prepared by first dissolving them in dimethyl sulfoxide (DMSO). All inhibitor samples were prepared by first dissolving them in dimethyl sulfoxide (DMSO). To dilute the samples, MOPS buffer at concentration $50 \mathrm{mM}$ (pH 6.9) was used. They were then added with CAll solution. Esterase activity was measured by adding 4-NPA substrate to the mixture and incubating it for $2 \mathrm{~h}$ at $25^{\circ} \mathrm{C}$. The hydrolysis of the substrate was then evaluated at $405 \mathrm{~nm}$ using a Biorad Elisa Reader. The percent inhibition for each sample was calculated as.

Inhibition $(\%)=\{(\mathrm{C}-\mathrm{T}) / \mathrm{C}\} 100$

where C (i.e., control) = total enzyme activity without inhibitor and $\mathrm{T}$ (i.e., test sample) = activity in the presence of test compound.

Inhibitory activity was expressed as $\mathrm{IC}_{50}$ values (the concentration at which $50 \%$ of the enzyme activity inhibited), which were calculated using Microsoft Excel 2011 from a dose-response curve obtained using at least five concentrations (ranging from $1-10 \mu \mathrm{g} / \mathrm{mL}$ ) of the inhibitor and carried out in triplicate.

\section{Molecular docking}

The initial structure of CA-II was obtained from the protein data bank (PDB), accession code 2Q38 [14]. Redocking LSA503 to the CA-II crystal structure was performed to derive docking parameters that will be used for the docking simulation with curcumin analogs. All ligand structures were prepared by the Marvin Sketch program [15]. Molecular docking simulations were observed by Autodock Vina and a genetic algorithm was used for exploring ligand poses inside the active site of CA-II [16]. Schematic representations of the ligand poses and interactions were generated by LigPlot programs [17].

\section{Statistical analysis}

Measurements were carried out in triplicate and the results presented as mean \pm SEM. Statistical analysis was performed by t-test using Microsoft Excel 2011, and $p<0.05$ was considered statistically significant.

\section{RESULTS}

\section{CA-II inhibition}

In order to evaluate the potential of the 44 curcumin analogs listed in Table 1 to inhibit CA-II activity, we first measured the CA-II activity in the absence and presence of each analog. The level of inhibition was expressed as the percentage difference in CA-II activity before and after the addition of the inhibitor (Table 2). Compounds a7, a8, a9, a10, a13, a14, a15, a16, b1, b3, b7, b10, b11, b14, c3, c11, c14, and c16 showed no inhibitory activities; compounds a2, a4, a5, a11, a12, b2, b4, b6, b8, b12, b13, b15, b16, c1, c2, c4, c8 exhibited inhibition below $40 \%$. Only eight

Table 2: List of ligand molecules and their inhibitory activity against CA-II

\begin{tabular}{lccccc}
\hline Compound & Inhibition (\%) & Compound & Inhibition (\%) & Compound & Inhibition (\%) \\
\hline a1 & 81.44 & b1 & - & $c 1$ & 27.09 \\
a2 & 8.89 & b2 & 8.02 & c2 & 22.20 \\
a3 & 49.37 & b3 & - & c3 & - \\
a4 & 11.43 & b4 & 17.71 & c4 & 19.09 \\
a5 & 14.90 & b6 & 18.42 & c6 & 40.65 \\
a7 & - & b7 & - & c7 & 48.66 \\
a8 & - & b8 & 3.79 & c8 & 19.09 \\
a9 & - & b9 & 40.60 & $c 9$ & 41.32 \\
a10 & - & b10 & - & c10 & 58.50 \\
a11 & 7.56 & b11 & - & c11 & - \\
a12 & 0.68 & b12 & 15.62 & c12 & 53.45 \\
a13 & - & b13 & 12.41 & c13 & 43.25 \\
a14 & - & b14 & - & c14 & - \\
a15 & - & b15 & 14.85 & c16 & - \\
a16 & - & b16 & 12.30 & & \\
\hline
\end{tabular}




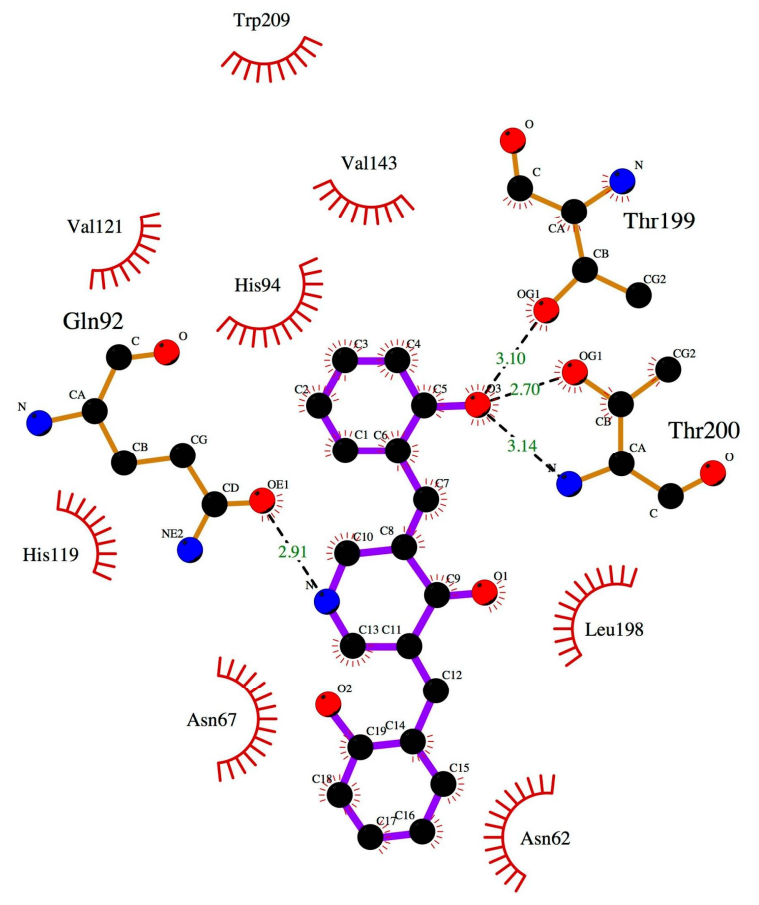

Figure 2: Schematic representation of the binding mode of a1 to the CA-II active site

analogs exhibited inhibition levels greater than $40 \%$ : a1 (81.44 \%), a3 (49.63\%), b9 (40.60\%), c7 (48.66\%), c10 (58.50\%), c6 (40.65\%), c12 (53.45\%), and c13 (43.25\%). Therefore, only these eight compounds were further evaluated by measurement of their $\mathrm{IC}_{50}$ values.

The $\mathrm{IC}_{50}$ values of these analogs ranged from $7.92 \pm 0.54 \mu \mathrm{M}$ to $72.31 \pm 2.21 \mu \mathrm{M}$ (

Table 2: List of ligand molecules and their inhibitory activity against CA-II

\begin{tabular}{lccccc}
\hline Compound & Inhibition (\%) & Compound & Inhibition (\%) & Compound & Inhibition (\%) \\
\hline a1 & 81.44 & b1 & - & $c 1$ & 27.09 \\
a2 & 8.89 & b2 & 8.02 & c2 & 22.20 \\
a3 & 49.37 & b3 & - & c3 & - \\
a4 & 11.43 & b4 & 17.71 & c4 & 19.09 \\
a5 & 14.90 & b6 & 18.42 & c6 & 40.65 \\
a7 & - & b7 & - & c7 & 48.66 \\
a8 & - & b8 & 3.79 & c8 & 19.09 \\
a9 & - & b9 & 40.60 & $c 9$ & 41.32 \\
a10 & - & b10 & - & $c 10$ & 58.50 \\
a11 & 7.56 & b11 & - & $c 11$ & - \\
a12 & 0.68 & b12 & 15.62 & $c 12$ & 53.45 \\
a13 & - & b13 & 12.41 & $c 13$ & 43.25 \\
a14 & - & b14 & - & c14 & - \\
a15 & - & b15 & 14.85 & $c 16$ & - \\
a16 & - & b16 & 12.30 & & \\
\hline
\end{tabular}

). The compound with the lowest $\mathrm{IC}_{50}$ value, i.e., the most potent inhibitor among all of the assayed curcumin analogs, was compound a1, (3E, 5E)-3,5-bis[(2-hydroxyphenyl) methylidene]piperidin-4-one.

Table 3: Inhibition of CA-II with curcumin analogs

\begin{tabular}{ll}
\hline Compound & $\mathbf{I C}_{50}(\boldsymbol{\mu M})$ \\
\hline a1 & $7.92 \pm 0.54$ \\
\hline
\end{tabular}




\begin{tabular}{lc}
\hline $\mathrm{c} 12$ & $12.37 \pm 0.78$ \\
$\mathrm{c} 10$ & $15.80 \pm 0.76$ \\
$\mathrm{c} 13$ & $18.13 \pm 0.17$ \\
$\mathrm{c} 6$ & $21.85 \pm 1.97$ \\
$\mathrm{c} 7$ & $30.45 \pm 0.94$ \\
$\mathrm{a} 3$ & $38.31 \pm 0.46$ \\
$\mathrm{~b} 9$ & $72.31 \pm 2.21$ \\
\hline
\end{tabular}

\section{Molecular docking results}

A schematic representation of the binding mode of a1 to CA-II, as found during the molecular docking studies is shown in Figure 2.

\section{DISCUSSION}

Based on the above analysis, we observed a correlation between the position of the hydroxyl group and the inhibition potential of the curcumin analogs. The presence of a hydroxyl group at $R_{2}$ (ortho position) in a1 molecule apparently cause increasing of inhibition against CA-II compared to the presence of hydroxyl group at $\mathrm{R}_{3}$ as in $\mathrm{a} 4, \mathrm{~b} 4$, and $\mathrm{c} 4$; or at $\mathrm{R}_{4}$ as in $\mathrm{a} 8, \mathrm{~b} 8$, and $\mathrm{c8}$. Substitution of the hydroxyl group at the $R_{2}$ position with more rigid groups, such as methoxy and benzyl groups, decreased the inhibitory capacity of the molecules. However, compounds $\mathrm{c} 1$ and $\mathrm{b} 1$ with a hydroxyl group at $R_{2}$ exhibited contrasting results with a1, and both molecules showed low levels of inhibition towards CA-II activity. This suggests that the hydroxyl group may not be the only contributor to the inhibitory capacity of the curcumin analogs. Other types of interactions may also play roles that strengthen interactions with the enzyme.

In order to further investigate how the a1 molecule exhibited its strong inhibitory capacity against CA-II activity, we performed a molecular docking simulation using Autodock Vina. The docking result gave insight into the role of some of the functional groups in the a1 molecule that contribute to strengthening its interactions at the molecular level with residues inside the active site of the enzyme. We found that the oxygen atom of the hydroxyl group attached at the $R_{2}$ position of a1 strongly interacted via hydrogen bonding with the Thr199 and Thr200 residues that are located near the entrance of the active site cavity.

Another hydrogen bond occurred between the $\mathrm{N}$ atom at the $R_{1}$ position of a1 and Gln92. We propose that interaction of the $\mathrm{N}$ atom at $\mathrm{R}_{1}$ has a dominant effect on the inhibitory activity of CAII compared with the hydroxyl interaction at the ortho position. In addition, hydrophobic interactions among nonpolar moieties of the a1 molecule with the nearest nonpolar residues also contributed to stabilizing the position of the a1 molecule inside the CA-II active site. Interestingly, a $\mathrm{Zn}^{2+}$ ion was not directly involved in the stabilization of the a1 molecule, while most inhibitor molecules, such as the CA-II inhibitor acetazolamide, are strongly bound to this ion [12].

Previously, curcumin has been shown to inhibit CA-II [9]. In this study, eight new curcumin analogs also showed to effectively inhibit CA-II at the micromolar range.

\section{CONCLUSION}

The findings of this study indicate that curcumin analogs can be used as inhibitors of CA-II. Eight of the compounds demonstrated the potential to inhibit CA-II activity. The most effective inhibitor found in the present study is (3E, $5 \mathrm{E})-3,5$-bis[(2hydroxyphenyl) methylidene]piperidin-4-one, which is also supported by molecular docking results. This curcumin analog strongly interacts with the residues Thr199, Thr200 and Gln92 in the active site of CA-II. Thus, these findings show facilitate the development of novel CA-II inhibitors for glaucoma treatment.

\section{DECLARATIONS}

\section{Acknowledgement}

This work was funded by Institut Teknologi Bandung research grant (contract no. 006g/l1.C01/PL/2016) awarded to Rukman Hertadi.

\section{Conflict of Interest}

No conflict of interest associated with this work.

\section{Contribution of Authors}

The authors declare that this work was done by the authors named in this article and all liabilities pertaining to claims relating to the content of this article will be borne by them.

\section{Open Access}

This is an Open Access article that uses a funding model which does not charge readers or their institutions for access and distributed under the terms of the Creative Commons Attribution License (http://creativecommons.org/licenses/by/ 4.0) and the Budapest Open Access Initiative (http://www.budapestopenaccessinitiative.org/rea d), which permit unrestricted use, distribution, 
and reproduction in any medium, provided the original work is properly credited.

\section{REFERENCES}

1. Kidani $Y$, Hirose J, Koike H. Coordination chemical studies on metalloenzymes. Kinetics and mechanism of the $\mathrm{Zn}$ (II) exchange reaction between chelating agent and apo-bovine carbonic anhydrase. J Biochem 1976; 79(1): 43-51. PMID: 820693.

2. Hassan MI, Shajee B, Waheed A, Ahmad F, Sly WS. Structure, function and applications of carbonic anhydrase isozymes. Bioorg Med Chem 2012; 21: 15701582. doi:10.1016/j.bmc.2012.04.044

3. Patil S, Reshetnikov S, Haldar MK, Seal S, Mallik S. Surface-derivatized nanoceria with human carbonic anhydrase II inhibitors and fluorophores: a potential drug delivery device. J Phy Chem B 2007; 111(24): 84378442. doi: 10.1021/jp0676661.

4. Aggarwal M, Kondeti B, McKenna R. Insights towards sulfonamide drug specificity in a-carbonic anhydrases. Bioorg Med Chem 2013; 21: 1526-1533. doi: 10.1016/j.bmc.2012.08.019.

5. Supuran CT, Scozzafava A, Casini A. Carbonic anhydrase inhibitors. Med Res Rev 2003; 23(2): 146189. DOI 10.1002/med. 10025

6. Supuran CT. Carbonic anhydrase inhibitors. Bioorg Med Chem Lett 2010; 20: 3467-3474. doi:10.1016/j. bmcl.2010.05.009.

7. Sethi K, Verma SM, Posa MK, Kumar R, Supuran CT. Carbonic anhydrase I and II inhibition with natural products: Leucas cephalotes. Pharmacogn Commun 2011; 1(2): 41-46. doi: 10.5530/pc.2011.2.8.

8. Sahin $H$, Can Z, Yildiz O, Kolayli S, Innocenti A, Scozzafava G, Supuran CT. Inhibition of carbonic anhydrase isozymes I and II with natural products extracted from plants, mushrooms and honey. J Enzyme Inhib Med Chem 2012; 27(3): 395-402. doi: 10.3109/14756366.2011.593176.
9. Şentürk, M, Gülçin I, Beydemir Ş, Küfrevioğlu Öl, Supuran CT. In Vitro Inhibition of Human Carbonic Anhydrase I and II Isozymes with Natural Phenolic Compounds. Chem Biol Drug Des 2011; 77: 494-499. doi: 10.1111/j.1747-0285.2011.01104.x.

10. Eryanti $Y$, Herlina $T$, Zamri A, Halim SNA, Shiono $Y$, Syah YM, Awang $K$, Supratman U. 3,5-Bis(2hydroxybenzylidene)piperidin-4-one. Molbank 2014; 2014(2): M825. doi: 10.3390/M825.

11. Huang $H Q$, Pan $X$, Ji CJ, Zeng GZ, Jiang $L H$, Fu X, Liu JK, Hao XJ, Zhang YJ, Tan NH. Screening and docking studies of natural phenolic inhibitors of carbonic anhydrase II. Sci China Ser B Chem 2009; 52(3): 332337.

12. Nishimori I, Minakuchi $T$, Vullo $D$, Scozzafava $A$, Innocenti $A$, Supuran CT. Carbonic anhydrase inhibitors. Cloning, characterization, and inhibition studies of a new beta-carbonic anhydrase from Mycobacterium tuberculosis. J Med Chem 2009; 52(9): 3116-3120. doi: 10.1021/jm9003126.

13. Maryanoff BE, McComsey DF, Costanzo MJ, Hochman $C$, Smith-Swintosky $V$, Shank RP. Comparison of sulfamate and sulfamide groups for the inhibition of carbonic anhydrase-ll by using topiramate as a structural platform. J Med Chem 2005; 48(6): 19411947. PMID: 15771438.

14. Köhler K, Hillebrecht $A$, Wischeler JS, Innocenti A, Heine $A$, Supuran $C T$, Klebe G. Saccharin inhibits carbonic anhydrases: possible explanation for its unpleasant metallic aftertaste. Angew Chem Int Ed Engl 2007; 46(40): 7697-7699. doi: 10.1002/anie.200701189.

15. ChemAxon. 2012. Marvin 5.10.0. 2012. Available from: URL: http://www.chemaxon.com.

16. Trott O, Olson AJ. AutoDock Vina: improving the speed and accuracy of docking with a new scoring function, efficient optimization and multithreading. J Comput Chem 2010; 31(2): 455-461. doi: 10.1002/jcc.21334.

17. Wallace AC, Laskowski RA, Thornton JM. LIGPLOT: a program to generate schematic diagrams of proteinligand interactions. Protein Eng 1995; 8(2): 127-134. PMID: 7630882 . 